\title{
Article
}

\section{Heteroalleles in Common Wheat: Multiple Differences between Allelic Variants of the Gli-B1 Locus}

\author{
Eugene Metakovsky ${ }^{1}$, Laura Pascual ${ }^{1, *}$, Patrizia Vaccino ${ }^{2}{ }^{(0}$, Viktor Melnik ${ }^{3}{ }^{(}$, Marta Rodriguez-Quijano $^{1}$, \\ Yulia Popovych ${ }^{4} \mathbb{D}$, Sabina Chebotar ${ }^{4}$ and William John Rogers ${ }^{5}$
}

check for

updates

Citation: Metakovsky, E.; Pascual, L.; Vaccino, P.; Melnik, V.;

Rodriguez-Quijano, M.; Popovych, Y.;

Chebotar, S.; Rogers, W.J.

Heteroalleles in Common Wheat:

Multiple Differences between Allelic

Variants of the Gli-B1 Locus. Int. J.

Mol. Sci. 2021, 22, 1832.

https://doi.org/10.3390/

ijms22041832

Academic Editor: Richard R.-C. Wang

Received: 30 November 2020

Accepted: 7 February 2021

Published: 12 February 2021

Publisher's Note: MDPI stays neutral with regard to jurisdictional claims in published maps and institutional affiliations.

Copyright: (c) 2021 by the authors. Licensee MDPI, Basel, Switzerland. This article is an open access article distributed under the terms and conditions of the Creative Commons Attribution (CC BY) license (https:/ / creativecommons.org/licenses/by/ $4.0 /$ )
1 Department of Biotechnology-Plant Biology, School of Agricultural, Food and Biosystems Engineering, Universidad Politécnica de Madrid, 28040 Madrid, Spain; emetakovsky@gmail.com (E.M.); marta.rurquiaga@upm.es (M.R.-Q.)

2 Consiglio per la Recerca in Agricultura e l'Analisi dell'Economia Agraria, Research Centre for Cereal and Industrial Crops, 13100 Vercelli, Italy; patrizia.vaccino@crea.gov.it

3 Vavilov Institute of General Genetics RAS, 117971 Moscow, Russia; meller@vigg.ru

4 Department of Genetics and Molecular Biology, National I.I. Mechnikov University, 65058 Odessa, Ukraine; popovych1818@gmail.com (Y.P.); s.v.chebotar@onu.edu.ua (S.C.)

5 Departamento de Biología Aplicada, CIISAS, CIC-BIOLAB, CONICET-INBIOTEC, CRESCA, Facultad de Agronomía, Universidad Nacional del Centro de la Provincia Buenos Aires, 7300 Azul, Provincia de Buenos Aires, Argentina; rogers@faa.unicen.edu.ar

* Correspondence: laura.pascual@upm.es

\begin{abstract}
The Gli-B1-encoded $\gamma$-gliadins and non-coding $\gamma$-gliadin DNA sequences for 15 different alleles of common wheat have been compared using seven tests: electrophoretic mobility (EM) and molecular weight (MW) of the encoded major $\gamma$-gliadin, restriction fragment length polymorphism patterns (RFLPs) (three different markers), Gli-B1- $\gamma$-gliadin-pseudogene known SNP markers (Single nucleotide polymorphisms) and sequencing the pseudogene GAG56B. It was discovered that encoded $\gamma$-gliadins, with contrasting EM, had similar MWs. However, seven allelic variants (designated from I to VII) differed among them in the other six tests: I (alleles Gli-B1i, $k, m, o)$, II (Gli-B1n, $q, s)$, III (Gli-B1b), IV (Gli-B1e,f,g), V (Gli-B1h), VI (Gli-B1d) and VII (Gli-B1a). Allele Gli-B1c (variant VIII) was identical to the alleles from group IV in four of the tests. Some tests might show a fine difference between alleles belonging to the same variant. Our results attest in favor of the independent origin of at least seven variants at the Gli-B1 locus that might originate from deeply diverged genotypes of the donor(s) of the B genome in hexaploid wheat and therefore might be called "heteroallelic". The donor's particularities at the Gli-B1 locus might be conserved since that time and decisively contribute to the current high genetic diversity of common wheat.
\end{abstract}

Keywords: Triticum aestivum; Gli-B1; $\gamma$-gliadin polymorphism; APAGE; PCR; DNA sequencing

\section{Introduction}

Wheat is globally one of the most important crops. Currently, with world production at 728.5 million tonnes and a sown area covering 214 million hectares in 2019, wheat includes a quarter of total cereal production [1]. Wheat production includes two different polyploidy species derived from natural hybridization events [2], the tetraploid species (AABB) durum wheat (Triticum turgidum L.) and the hexaploid species (AABBDD) bread wheat (Triticum aestivum L.). Bread wheat represents roughly 90 to $95 \%$ of the total production; hence, any advances related to knowledge or breeding in this species will have a major worldwide impact.

Wheat provides $20 \%$ of the daily protein and food calorie intakes worldwide and represents one of the major protein components of the human diet. In recent decades, there has been an unprecedented increase in knowledge of the chemistry, genetics and functionality of the main proteins of the wheat seed, gliadin and glutenin. For example, there are classifications of different alleles at the seed-storage-protein-encoding loci in their 
relation to dough quality. This knowledge helps the production of new genotypes with improved characteristics (including field, dough-quality and medical aspects). However, the immense complexity of the bread wheat genome $(2 n=6 x=42,17 \mathrm{~Gb})$ and of the genetic loci encoding the synthesis of the gliadins and glutenins leaves many questions unanswered. Such as the fact the same protein alleles might have different relationships to dough quality. Such findings raise the question of whether these alleles, identified by protein analysis in unrelated cultivars, are indeed identical. Moreover, the degree of difference at the DNA level of allelic variants differing on the protein level at the same seed-storage-protein-encoding locus is unknown.

A common wheat genotype produces more than 50 different polypeptides of gliadin (gliadins) [3,4]. The primary structure of several hundred gliadin-coding DNA sequences from different wheat species has been studied, and three main types of gliadin polypeptides differing between them in primary structure and biochemical properties, the so-called $\alpha-, \gamma-$ and $\omega$-gliadins, have been described [5]. Moreover, each type, for example, the $\gamma$-gliadins [6,7], is composed of a number of families, meaning that members of a given family are more similar than members of different families.

About 20-25 bands differing in electrophoretic mobility (EM) may be observed in a one-dimensional electrophoregram (acid polyacrylamide gel electrophoresis, APAGE) of a single grain, encoded in common wheat by six major (Gli-A1, Gli-B1, Gli-D1, Gli-A2, Gli-B2, Gli-D2) [8] and several minor [9] Gli loci. Analysis of segregating progenies from crosses between wheat genotypes showed that any Gli allele encodes two or more gliadin polypeptides (a block of electrophoretic bands) inherited together as a Mendelian unit. Alleles at one Gli locus differ in the number and/or EM of the encoded gliadin polypeptides of different gliadin types [10]. In total, there are currently about 180 known alleles at the six major loci [11].

A fundamental characteristic of the seed-storage-protein-coding loci (for example, of the tightly linked Gli-1 and Glu-3 loci mapped in the distal part of the short arms of the homoeologous group 1 chromosomes [8]), is their great complexity. The size of one storage protein gene, including its regulatory sequences, is known to be about $0.8-1.5 \mathrm{~Kb}$ [12-14], but the distance between these genes has been shown to be very large, reaching $55-120 \mathrm{~Kb}$ per $1 \mathrm{cM}$ of genetic distance $[15,16]$. The average distance between active genes was about $81 \mathrm{~Kb}$ [14], and the distance of $10 \mathrm{~Kb}$ between two gliadin genes, tenfold the length of a gliadin gene itself, may be considered as exceptionally short, besides the fact that the genes can be considered to be clustered [16]. The size of an entire Gli locus encoding several gliadin polypeptides may exceed $2000 \mathrm{~Kb}$ as suggested for the Gli-A2 locus [17].

Hence all expressed gliadin genes together occupy only a minor part of the DNA of a Gli locus. The largest part of a Gli locus was shown to consist of non-coding DNA sequences represented mainly by different types of transposable elements $[16,18,19]$, but also by gliadin pseudogenes and gene fragments [20] for which inter-varietal polymorphism was described [21] and even some non-gliadin genes and sequences with open reading frames $[16,22,23]$. Therefore, allelic variants of a Gli locus may differ in the number and types of active genes, in the distance between them, in the quota of pseudogenes among all the gliadin sequences and, probably, in the presence of non-gliadin genes harbored within a given Gli locus. The polymorphism of an entire Gli locus could be further augmented by the presence of single nucleotide polymorphisms (SNP).

Alleles at a Gli locus are routinely identified by the use of APAGE of gliadin proteins, thereby revealing sets of transcribed genes within the locus. However, an allele identified by APAGE may differ, in different genotypes, in the non-coding part of the locus. Hence alleles identified by APAGE may only be considered as markers of corresponding allelic variants of Gli loci.

There are few possibilities to compare allelic variants of an entire Gli locus, including its non-coding sequences. Restriction fragment length polymorphism (RFLP) analysis may disclose a difference between the alleles in the distribution of gliadin-coding sequences (including pseudogenes) along the whole locus. Two sets of molecular probes were also 
made available for the analysis of gliadin-coding DNA sequences. Firstly, the GAG56B $\gamma$-gliadin pseudogene was detected with the gene-specific PCR primer pair GAG29/30, and one of the variants of the pseudogene sequence (p-aes) was proven to be a characteristic of common wheat T. aestivum [24]. Secondly, two allele-specific PCR markers were developed for the Gli-B1- $\gamma$-gliadin sequence (probable pseudogene). Australian common wheat cultivars tested with these markers gave one PCR product with one pair of primers of either 369 or $397 \mathrm{bp}$ [25].

Thus, a Gli- locus is a highly complex chromosomic fragment that includes several gliadin-encoding genes, pseudogenes and sequences unrelated to gliadins. Some allelic variants at the Gli loci (and at the Glu-3 loci tightly linked to Gli-1) have been related to dough quality, providing useful markers to conduct quality breeding. However, the same allele at the Gli locus identified by protein electrophoresis in different cultivars might apparently have different relationships to dough quality, suggesting that this allele might be represented by more than one variant and tampering with the usefulness of gliadins as molecular markers. In order to explore this question, in this work, we compared 15 allelic variants at the Gli-B1 locus of common wheat (identified as blocks of Gli-B1-encoded gliadin polypeptides in APAGE) by means of several approaches: firstly, EM and molecular weight (MW) of encoded $\gamma$-gliadins using two-dimensional electrophoresis; secondly, their RFLP patterns (three different restriction enzymes and a $\gamma$-gliadin-specific probe); thirdly, the length of the PCR sequence of the $\gamma$-gliadin pseudogene; and fourthly, the DNA sequence of another $\gamma$-gliadin pseudogene present within the Gli-B1 locus. It was shown that the alleles studied might be divided into several variants strongly differing between them in their coding, as well as non-coding, sequences. The simultaneous multiple differences (without intermediate forms) among versions of the Gli-B1 locus may be explained through the suggestion that these variants maintain the particularities of the original genotypes of the corresponding diploid donor(s) in hexaploid wheat.

\section{Results}

\subsection{Alleles at the Gli-B1 Locus Identified by APAGE}

Twenty-four alleles at the Gli-B1 locus (including the null-allele and the Gli-B1l allele which designates the 1BL.1RS translocation) have been revealed in the wheat germplasm studied [11], and 16 of them, including Gli-B1l, were selected for further analysis.

Examples of gliadin electrophoregrams (APAGE) of the common wheat cultivars carrying the alleles studied (Figure 1) and schemes of blocks of jointly inherited gliadin bands (Figure S1) are shown.

Alleles producing the slowest-moving $\gamma$-gliadin and alleles Gli-B1n, $q, s$ and $h$ are commonly accompanied by the allele Gli-B5b of the Gli-B5 locus, tightly linked to Gli$B 1$ [26]. The allele Gli-B5b encodes a pair of faint $\omega$-gliadins, while the allele Gli-B5a is null. Allelic variation at Gli-B5 was accepted as a polymorphism procured by the distal part of chromosome $1 \mathrm{~B}$, and $\omega$-gliadins encoded by the Gli-B5b were considered as a part of the Gli-B1-encoded blocks [11].

Each allele at the Gli-B1 locus of common wheat produces one $\gamma$-gliadin (the Gli-B1a encodes two $\gamma$-gliadins), two or more $\omega$-gliadins and some bands in the $\beta$-zone of the APAGE electrophoregram (Figure S1). At least seven variants of the EM of the Gli-B1encoded $\gamma$-gliadin (therefore, of the locus) were revealed: Gli-B1i, $m, k, o$ (variant I, the slowest EM); Gli-B1n, q, s (II); Gli-B1b (III); Gli-B1e, g (IV); Gli-B1h (V); Gli-B1d (VI); and Gli-B1a (VII, the fastest) (Figure 1). The allele Gli-B1f produces a slightly faster $\gamma$-gliadin compared to alleles of variant IV (Figure 11,j,k), but nevertheless may be attributed to this variant due to the similarity of other APAGE bands composing a block. For the same reason (the composition of the encoded block), the allele Gli-B1b was assumed to be different from alleles of the group IV. 

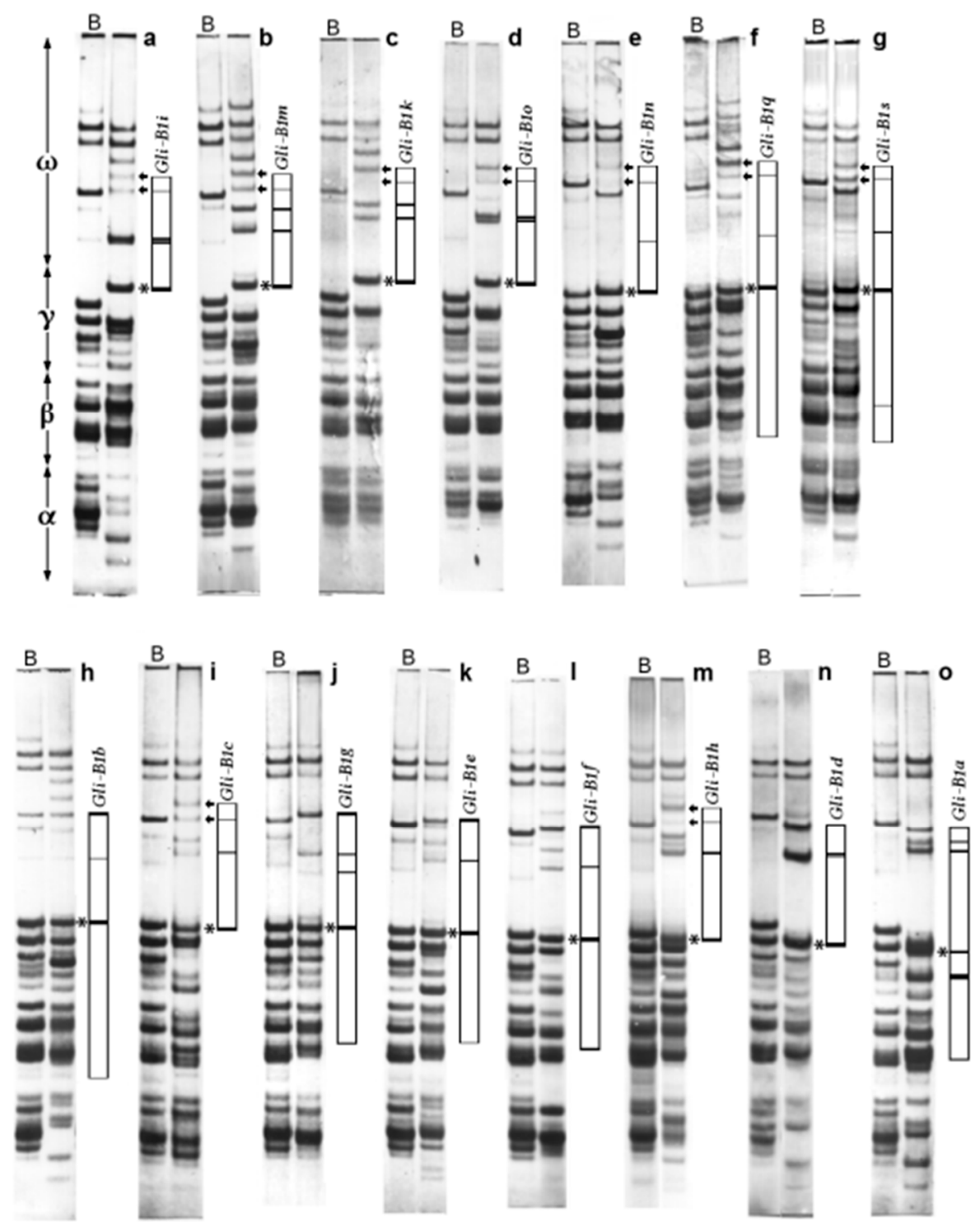

Figure 1. APAGE electrophoregrams of standard common wheat cultivars carrying different alleles at the Gli-B1 locus. (a), Insignia (Australia); (b), Silvana (Romania); (c), Pyrotrix-28 (Kazakhstan); (d), Levent (Bulgaria); (e), Intensivnaya (Kirgizstan); (f), Lesostepka-75 (Ukraine); (g), Est-Mottin (Italy); (h), Marquis (Canada); (i), Siete-Cerros-66 (Mexico); (j), Galahad (UK); (k), Solo (Germany); (1), Ducat (France); (m), Barbilla-Leon (Spain); (n), Caprock (USA); (o), Chinese Spring (China). $\mathrm{B}$, universal standard cultivar Bezostaya-1 (Gli-B1b) (Russia) [11]. The major $\gamma$-gliadin encoded at the Gli-B1 locus (asterisk) and $\omega$-gliadins encoded by the allele Gli-B5b (arrows) are indicated. $\alpha, \gamma$ and $\omega$, mark the protion of the electrophonegrams where $\alpha-, \gamma$ - and $\omega$-gliadins migrate respectively. The blocks of jointly inherited gliadin electrophoretic bands are shown schematically.

The allele Gli-B1c produces a weaker stained $\gamma$-gliadin and is linked to Gli-B5b (Figure 1i), thus differing from other alleles of group IV. Hence, the Gli-B1c might be considered as some kind of variation of variant IV or even a rather independent variant VIII of the Gli-B1 locus.

2.2. Apparent Molecular Weight of the Gli-B1-Encoded $\gamma$-Gliadins as Studied by Two-Dimensional APAGE $\times$ SDS Electrophoresis

The best way to compare the apparent MWs of the Gli-B1-encoded $\gamma$-gliadin polypeptides using two-dimensional electrophoresis (TDE) is to analyze a heterozygous seed of a cross between two genotypes carrying the alleles under study. Additionally, there is an 
"internal marker" present in most of the genotypes, the Gli-A3-controlled $\omega$-gliadin: allelic variants of this polypeptide show identical apparent MWs of about $41 \mathrm{kD}$ [9]. The major $\gamma$-gliadin encoded by the Gli-D1 locus (apparent MW of about $34 \mathrm{kD}$, data not shown) may be also used as an internal marker of MW (Figure 2 and Figure S2).
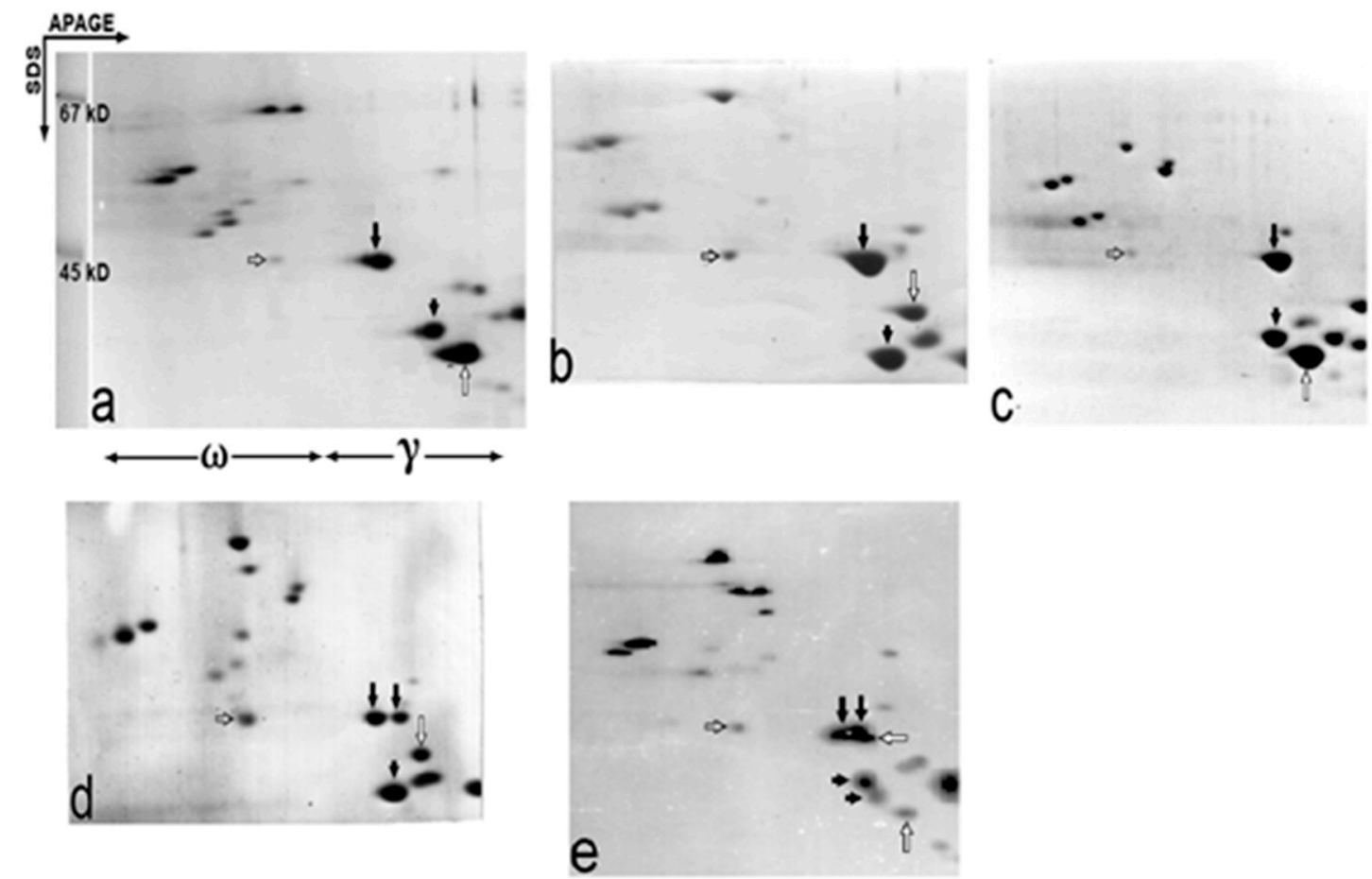

Figure 2. Two-dimensional (APAGE $\times$ SDS) separations of gliadin of common wheat cultivars and of F2 seeds of their crosses. (a), Skorospelka-U (Gli-B1m); (b), Tarasovskaya-29 (Gli-B1b); (c), Dneprovskaya-521 (Gli-B1d); (d), F2 seed heterozygous at the Gli-B1 from the cross between cultivars Rusalka (Gli-B1d) and Bezostaya-1 (Gli-B1b); (e), F2 seed heterozygous at each of the Gli-1 loci from the cross between Kharkovskaya-6 (Gli-A1j, Gli-B1e, Gli-D1i) and Skorospelka-U (biotype Gli-A1m, Gli-B1m, Gli-D1c). The long-tailed black arrows indicate the Gli-B1-encoded $\gamma$-gliadins, and the transparent short-tailed arrow shows the Gli-A3-controlled $\omega$-gliadin having an MW of $41 \mathrm{kD}$ ("internal marker"). The transparent long-tailed arrows, and the short-tailed black arrows, show the Gli-A1-encoded and the Gli-D1-encoded $\gamma$-gliadins, respectively. Only the $\gamma$ - and $\omega$-zones of the two-dimensional electrophoregram are shown.

The intriguing result of this approach seems to be a close similarity (identity) of the apparent MWs of $\gamma$-gliadins produced by any variant of the Gli-B1 locus (Figure 2 and Figure S2): Gli-B1-encoded $\gamma$-gliadins with different (including contrasting) EM had similar MWs of about $41 \mathrm{kD}$. For example, the MWs of $\gamma$-gliadins of alleles of variants I, III, VI (Figure 2a-c) and IV, II, V (Figure S2a-c, respectively) were hardly distinguishable by TDE. The close similarity of the MWs of these $\gamma$-gliadins was confirmed by analysis of heterozygous F2 seeds (Figure 2d).

Analysis of TD (APAGE $\times$ SDS) electrophoregrams published by different authors, as well as the results of our work, showed that alleles Gli-B1a, $b, c, d, e, f, g, h, k, m, o, q$ and $s$ each controlled $\gamma$-gliadin of similar MWs (Table S1). A new allele, Gli-B1v (differing slightly from the Gli-B1o in the EM of one $\omega$-gliadin), found in Spanish landraces also produced the $\gamma$-gliadin with an MW identical to those of variant I (Figure S2d). In durum wheat, known $\gamma$-gliadins $\gamma 42$ and $\gamma 45$ differing in their EM also have similar MWs of about $41 \mathrm{kD}$ (Figure 3 in [27]). 
(a)

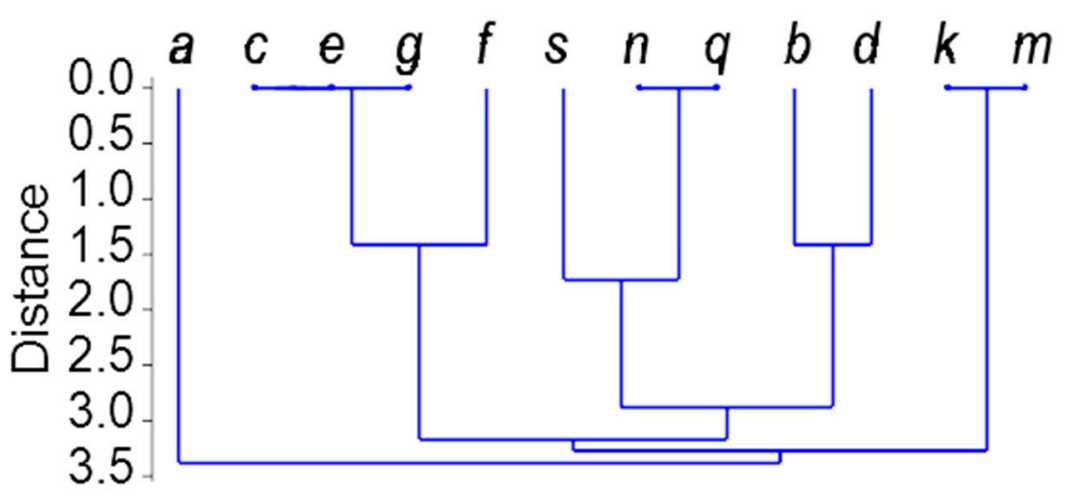

(b)

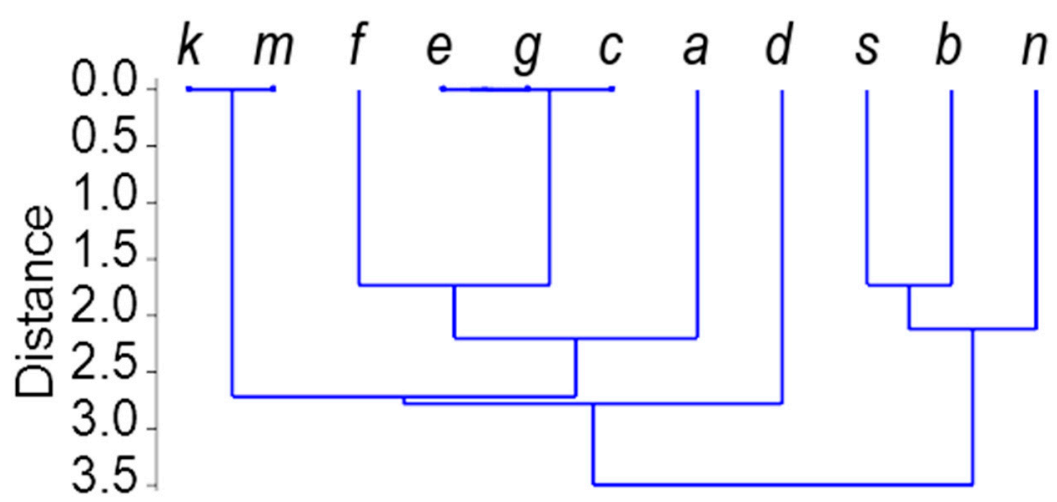

(c)

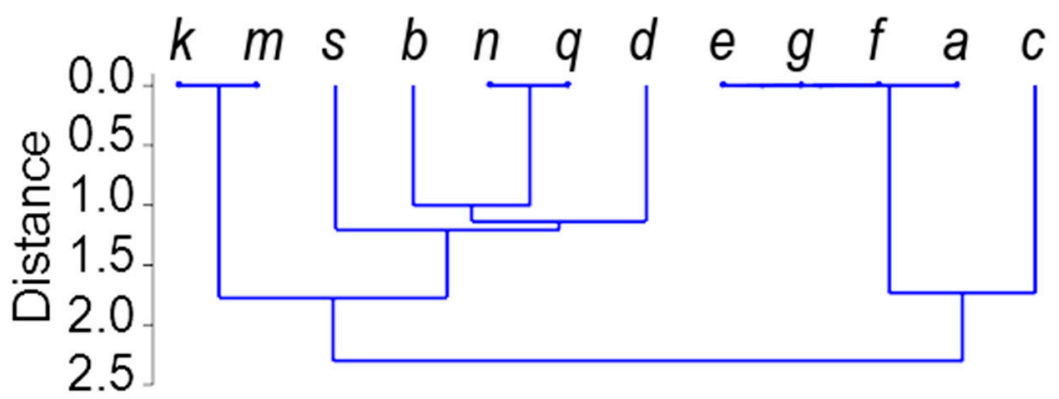

Figure 3. Relationships among alleles at the Gli-B1 locus based on the restriction fragment length polymorphism (RFLP) data. (a), TaqI; (b), RsaI; (c), HaeIII.

Although SDS-electrophoresis is hardly sensitive enough to document some probable minor differences in the length of compared polypeptides (for example, Figure 2e), it is clear that $\gamma$-gliadins controlled by different alleles at the Gli-B1 locus have a similar (if not identical) MW. Therefore, they did not meet the regularity (higher EM, lower MW) established earlier for the Gli-A1- and the Gli-D1-encoded $\gamma$-gliadins [28].

A general structure for the $\gamma$-gliadin-encoding genes and polypeptides is known [5-7]. The number of repeats and the length of the microsatellite present in the $\gamma$-gliadin gene sequence, as well as deletions or insertions, may influence the length (the MW) of the encoded $\gamma$-gliadin polypeptide. In contrast, considerable differences in the EM without noticeable alterations in their MW observed in our work, for example, among $\gamma$-gliadins of alleles Gli-B1m, $b, d$ (Figure 2a-c, respectively), may depend upon the number of charged amino acids present in these polypeptides of similar length.

\subsection{Gli-B1 Alleles Represented by RFLP Patterns}

Allelic variants of the Gli-B1 locus were studied by the RFLP approach using three different restriction enzymes TaqI, RsaI or HaeIII and the K32 probe, specific for the transcribed 
$\gamma$-gliadin sequences. Previous analysis of aneuploid lines of the cultivar Chinese Spring permitted identification of polymorphic DNA fragments belonging to the allele Gli-B1a in the RFLP pattern of this cultivar, and a congruity was established between the presence of definite polymorphic DNA fragments and some Gli-B1 alleles in wheat genotypes [29].

The RFLP-TaqI profiles (Figure S3) for 12 alleles at the Gli-B1 locus were compared, and 19 polymorphic bands were considered. The tree of relationships among Gli-B1 alleles drawn from their RFLP patterns (Figure 3) showed that the endonuclease TaqI did not distinguish between alleles Gli-B1m and k, Gli-B1n and $q$, and Gli-B1e and g. Sets of polymorphic bands of alleles Gli-B1s and Gli-B1f produced by TaqI were close to those of variants II and IV, respectively. For example, the difference between the Gli-BIf and other alleles of variant IV was in the position of only one RFLP fragment (Figure S3a; lane 1, band 19 , and lane 3 , band 16 , respectively). The RFLP-RsaI profiles produced 25 polymorphic bands (data not shown). The tree of relationships among Gli-B1 alleles (Figure 3b) was generally similar to that obtained using TaqI. However, in contrast to TaqI, alleles Gli-B1b and Gli-B1d had nothing in common when RsaI was used (Figure 3a,b).

The RFLP-HaeIII profiles produced only nine polymorphic bands, and the relationships among Gli-B1 alleles were different from those obtained using two other endonucleases. The most important findings were, first, an identity of the allele Gli-B1a with allelic variant IV, and, second, a considerable difference of the allele Gli-B1c from this variant (Figure 3c).

The results obtained with the RFLP approach show considerable differences in DNA sequence (positions of restriction sites) along the Gli-B1 locus among its alleles. There are six clear-cut allelic variants repeating those revealed by TDE, Gli-B1 $k$ and $m$ (variant I), Gli-B1n and $q(+s)(\mathrm{II})$, Gli-B1b (III), Gli-B1e and $g(+f)(\mathrm{IV})$, Gli-B1d (VI), and Gli-B1a (VII). Alleles of different variants do not share or share only a few identical Gli-B1-derived polymorphic DNA fragments recognized by the $\gamma$-gliadin-specific probe. Furthermore, the approach has permitted some fine differences to be revealed between alleles belonging to the same variant.

In accordance with the RFLP analysis, the allele Gli-B1c may represent one more variant (VIII), related to, but different from, alleles of group IV, as has already been suggested on the basis of APAGE data. The allele Gli-B1a seems to be related to variant IV (endonucleases RsaI and HaeIII).

There was no convincing identity of any RFLP band produced by genotypes carrying the allele Gli-B1l (the 1BL.1RS) and any other allele studied.

\subsection{Comparison of Alleles at the Gli-B1 Locus Using $\gamma$-Gliadin Pseudogene SNP Markers}

$\gamma$-Gliadin SNP markers (PCR primers GliB1.1 and GliB1.2) are specific for a pseudogene located inside the Gli-B1 locus. Each cultivar tested produced a PCR sequence with either primer GliB1.1 or GliB1.2, whereas cultivars carrying the 1BL.1RS translocation did not produce any amplification [25]. In our work, 16 alleles (including Gli-B1l) at the Gli-B1 locus were analyzed by this test (Figure 4; Table 1), and four main observations were drawn.

Firstly, all alleles at the Gli-B1 locus were divided into two groups, according to [25]. One group gave a PCR product with the GliB1.1 primer and included alleles of variants I (Gli-B1i, k, m, o), II (Gli-B1n, $q, s)$ and III (Gli-B1b). Another group (PCR product with the GliB1.2) was composed of all other alleles (Gli-B1a, $d, h, c, e, f, g)$ (Table 1). As expected, the cultivar Cartaya carrying the 1BL.1RS translocation (allele Gli-B1l) did not give a PCR product with any pair of primers.

Secondly, there was a polymorphism in the length of the PCR products (Product Length Polymorphism, PLP) (Figure 4, zone A). Three length variants were detected with the GliB1.1 primers (Figure 4a, lines 6-12) and four with GliB1.2 (Figure 4a, lines 1-5; Figure 4b, line 9). A polymorphism observed in zone B of the DNA electrophoregram (Figure 4) that included some PCR-derived DNA fragments of higher length was not considered. 

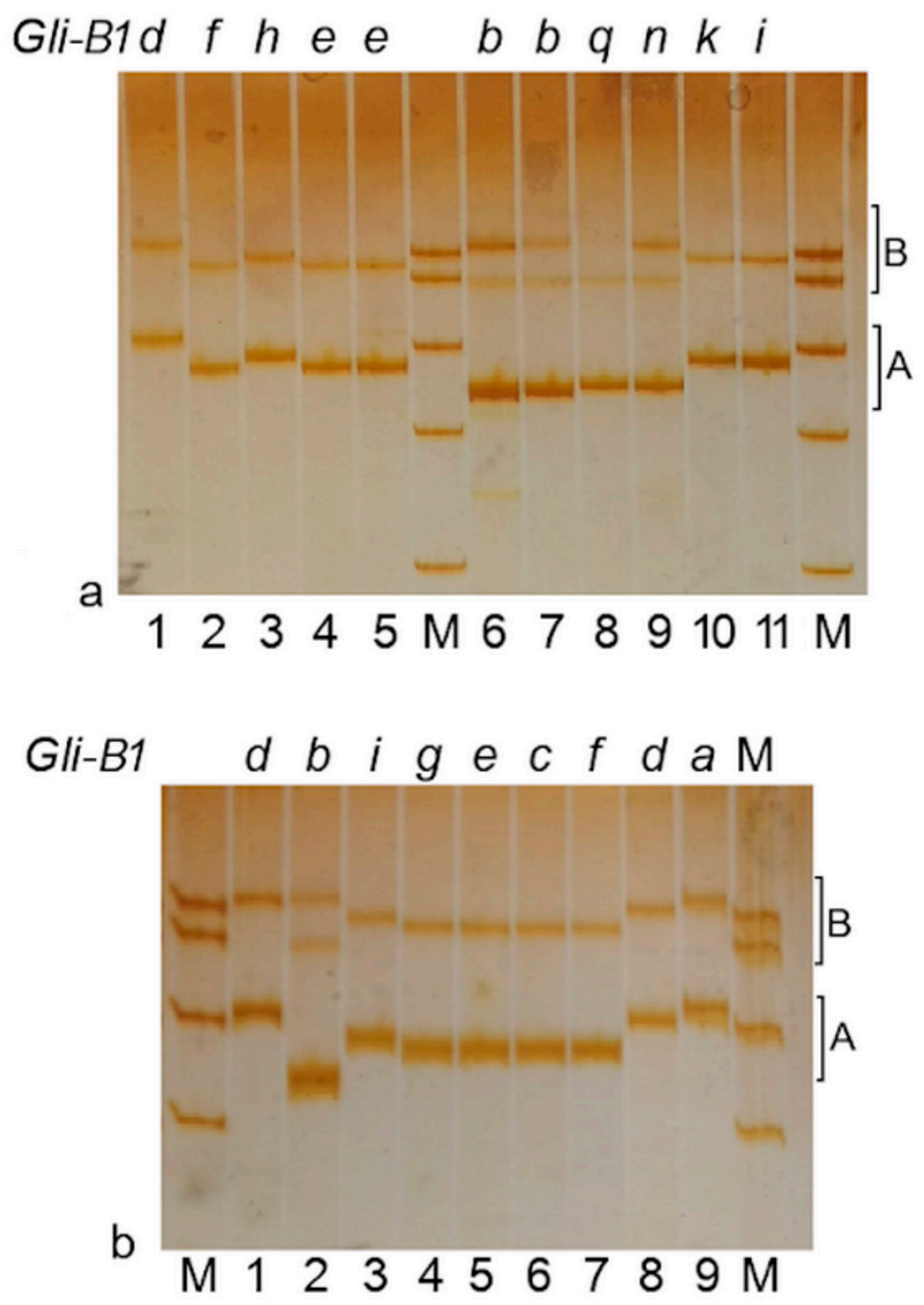

Figure 4. PCR (primers B1.1 or B1.2) Product Length Polymorphism (PLP) among alleles at the Gli-B1 locus. A and B represent two differentiated zones in the gel. Alleles at the Gli-B1 loci for each sample analyzed are indicated in the upper part of the gel. (a) 1, Pavon-F-76; 2, Cappelle-Desprez; 3, Ardec; 4, Escualo; 5, Glenlea; 6, Gabo; 7, Marquis; 8, Goelent; 9, Intensivnaya; 10, Mentana; 11, Insignia; 1-5, primers GliB1.2; 6-11, primers GliB1.1; (b) 1, Laura; 2, Bezostaya-1; 3, Insignia; 4, Galahad; 5, Escualo; 6, Prinqual; 7, Arminda; 8, Suneca; 9, Chinese-Spring; 1, 4-9 primers GliB1.2; 2, 3, primers GliB1.1. Alleles at the Gli-B1 locus are indicated above the lanes. M, marker pUC19/Mspl with DNA fragments of length 501, 489, 404, 331 and 242 bp, respectively. The polymorphism of the PCR-derived DNA fragments of higher length (zone B) was not considered in this work. 
Table 1. Cultivars studied, their alleles at the Gli-B1 locus, and the approximate length for the product obtained using GliB1.1 or GliB1.2 primers.

\begin{tabular}{cccccc}
\hline Cultivar & Country & Year & Allele & Primer & Length (bp) \\
\hline Bezostaya-1 & Russia & 1959 & $b$ & GliB1.1 & 369 \\
Gabo & Australia & 1942 & $b$ & GliB1.1 & 369 \\
Marquis & Canada & 1907 & $b$ & GliB1.1 & 369 \\
Insignia & Australia & 1946 & $i$ & GliB1.1 & 400 \\
Mentana & Italy & 1913 & $k$ & GliB1.1 & 400 \\
Titien & France & 1985 & $m$ & GliB1.1 & 400 \\
Aragon-03 & Spain & 1940 & $o$ & GliB1.1 & 400 \\
Intensivnaya & Kyrgyzstan & 1978 & $n$ & GliB1.1 & 372 \\
Goelent & France & 1985 & $q$ & GliB1.1 & 372 \\
Salmone & Italy & 1980 & $s$ & GliB1.1 & 372 \\
Cartaya & Spain & 1984 & $l$ & GliB1.1 or GliB1.2 & - \\
Chinese-Spring & China & - & $a$ & GliB1.2 & 415 \\
Pavon-F-76 & Mexico & 1971 & $d$ & GliB1.2 & 409 \\
Laura & Canada & 1986 & $d$ & GliB1.2 & 409 \\
Rinconada & Spain & 1981 & $d$ & GliB1.2 & 409 \\
Suneca & Australia & 1981 & $d$ & GliB1.2 & 409 \\
Prinqual & France & 1978 & $c$ & GliB1.2 & 397 \\
Escualo & Spain & 1981 & $e$ & GliB1.2 & 397 \\
Glenlea & Canada & 1972 & $e$ & GliB1.2 & 397 \\
Arminda & Netherlands & 1976 & $f$ & GliB1.2 & 397 \\
Cappelle-Desprez & France & 1946 & $f$ & GliB1.2 & 397 \\
Galahad & UK & 1983 & $g$ & GliB1.2 & 397 \\
Ardec & Belgium & 1979 & $h$ & GliB1.2 & 402 \\
Caia & Portugal & - & $h$ & GliB1.2 & 403 \\
\hline & & & &
\end{tabular}

Thirdly, an allele that is present in genotypes of different cultivars produced a PCR sequence of apparent identical length. For example, three cultivars from three countries with the allele Gli-B1b and four cultivars from four countries with the allele Gli-B1d produced PCR sequences of approximately $369 \mathrm{bp}$ (GliB1.1) and $409 \mathrm{bp}$ (GliB1.2), respectively (Table 1).

Fourthly, alleles encoding slow-moving $\gamma$-gliadin (Gli-B1i, $k, m, o$; Figure S1) gave a PCR product of identical length (Figure 4a, lines 10-12; Table 1). In addition, alleles of variant IV (Gli-B1e, $g, f)$ and allele Gli-B1c each produced an apparently identical PCR sequence of $397 \mathrm{bp}$ (Figure $4 \mathrm{~b}$, lines $4-7$ ).

Therefore, there are seven groups of alleles identified in accordance with the PLP. These groups are identical to those revealed by the APAGE, TDE and RFLP approaches: alleles Gli-B1i, k, m, o (variant I); Gli-B1n, q, s (II); Gli-B1b (III); Gli-B1e, $g$, $f$ (IV), Gli-B1h (V); Gli-B1d (VI); and Gli-B1a (VII). The allele Gli-B1c belongs, in this test, to variant IV.

\subsection{DNA Sequence of the $\gamma$-Gliadin Pseudogene GAG56B in Allelic Variants of the Gli-B1 Locus}

Seven cultivars studied for polymorphism in their $\gamma$-gliadin pseudogene $G A G 56 B$ of the Gli-B1 locus were divided into two groups by DNA sequence [24]. In the present work, von Büren's primers GAG29 and GAG30 were used and the resulting products were sequenced. In total, 30 cultivars from 15 countries representing 15 alleles at the Gli-B1 locus were compared (Table 2).

We were able to obtain a high-quality sequence between $170 \mathrm{bp}$ from the forward primer and $800 \mathrm{bp}$ for 29 cultivars. In Salmone, a high-quality sequence ranged from $200 \mathrm{bp}$ to $800 \mathrm{bp}$ (Figure S4). Aligning against the reference genebank accession M13712, we identified 14 positions with SNP, one of them (position 259) with three different possible nucleotides. Furthermore, the sequence included a single sequence repeat (SSR) CAA for which 10 possible variants of the length were detected. All these polymorphisms were combined in 11 different haplotypes (Figure 5; Table 2). 
Table 2. Variants of DNA sequences (haplotypes) of the pseudogene GAG56B in cultivars having different alleles at the Gli-B1 locus.

\begin{tabular}{|c|c|c|c|c|c|}
\hline Cultivar & Country & Year & Allele & $\begin{array}{c}\text { Haplotype } \\
\text { (Figure 5) }\end{array}$ & $\begin{array}{c}\text { EM of } \\
\gamma \text {-Gliadin }\end{array}$ \\
\hline Insignia & Australia & 1946 & $i$ & 1 & I \\
\hline Pane-247 & Spain & 1960 & $k$ & 1 & I \\
\hline Etoile-de-Choisy & France & 1950 & $m$ & 1 & I \\
\hline Aragon-03 & Spain & 1940 & $o$ & 1 & $\mathrm{I}$ \\
\hline Intensivnaya & Kyrgyzstan & 1978 & $n$ & 2 & II \\
\hline Spada & Italy & 1985 & $n$ & 2 & II \\
\hline Lesostepka-75 & Ukraine & 1945 & $q$ & 2 & II \\
\hline Salmone & Italy & 1980 & s & $2^{*}$ & II \\
\hline Alcalá & Spain & 1984 & $b$ & 3 & III \\
\hline Anza & Mexico, USA & 1971 & $b$ & 3 & III \\
\hline Glenlea & Canada & 1972 & $e$ & 4 & IV \\
\hline Marius & France & 1976 & $f$ & 4 & IV \\
\hline Pernel & France & 1983 & $f$ & 4 & IV \\
\hline Adalid & Spain & 1987 & $g$ & 4 & IV \\
\hline Calodine & Italy & 1991 & $g$ & 4 & IV \\
\hline Diego & Spain & - & c & 4 & VIII \\
\hline Prinqual & France & 1978 & $c$ & 4 & VIII \\
\hline Siete-Cerros-66 & Mexico & 1966 & $c$ & 4 & VIII \\
\hline Ardec & Belgium & 1979 & $h$ & 5 & $\mathrm{~V}$ \\
\hline Caia & Portugal & - & $h$ & 5 & $\mathrm{~V}$ \\
\hline Pepital & Netherlands & 1989 & $h$ & 5 & $\mathrm{~V}$ \\
\hline Cajeme-71 & Mexico & 1971 & $d$ & 6 & VI \\
\hline Chopin & France & 1984 & $d$ & 6 & VI \\
\hline Katepwa & Canada & 1981 & $d$ & 6 & VI \\
\hline Chinese-Spring & China & - & $a$ & 7 & VII \\
\hline Pyrotrix-28 & Kazakhstan & 1973 & $m$ & 8 & I \\
\hline Titien & France & 1985 & $m$ & 9 & $\mathrm{I}$ \\
\hline Astral & France & 1972 & $f$ & 10 & IV \\
\hline Floreal & France & 1984 & $f$ & 10 & $\mathrm{~V}$ \\
\hline Saratovskaya-39 & Russia & 1968 & $e$ & 11 & IV \\
\hline
\end{tabular}

${ }^{1}$ Variant of the electrophoretic mobility (APAGE) of the Gli-B1-encoded $\gamma$-gliadin (variant I, the slowest; variant VII, the fastest).

\begin{tabular}{|c|c|c|c|c|c|c|c|c|c|c|c|}
\hline nt position & Hap_1 & Hap_2 & Hap_3 & Hap_4 & Hap_5 & Hap_6 & Hap_7 & Hap_8 & Hap_9 & Hap_10 & Hap_11 \\
\hline 173 & $C$ & $C$ & C & C & $\mathrm{T}$ & C & $\mathrm{C}$ & C & $\mathrm{C}$ & C & C \\
\hline 182 & $\mathrm{C}$ & $\mathrm{C}$ & $T$ & $\mathrm{C}$ & $\mathrm{C}$ & $\mathrm{C}$ & $\mathrm{C}$ & $\mathrm{C}$ & $\mathrm{C}$ & $\mathrm{C}$ & $\mathrm{C}$ \\
\hline 259 & G & $T$ & $T$ & $\mathrm{G}$ & $A$ & G & G & G & G & G & G \\
\hline 279 & A & $C$ & $C$ & $C$ & $C$ & $C$ & $C$ & A & A & $C$ & $C$ \\
\hline 348 & C & C & C & C & C & C & C & C & C & G & C \\
\hline 413 & $C$ & $C$ & $C$ & $T$ & $C$ & C & $T$ & $C$ & $C$ & $T$ & $T$ \\
\hline 438 & $C$ & $C$ & $C$ & $\mathrm{C}$ & $T$ & $\mathrm{C}$ & $C$ & $C$ & $C$ & $C$ & $C$ \\
\hline 474 & $\mathrm{~T}$ & $\mathrm{C}$ & C & $T$ & $T$ & $T$ & $T$ & $\mathrm{~T}$ & $T$ & $T$ & $T$ \\
\hline 495 & A & A & A & A & $T$ & A & A & A & A & A & A \\
\hline 524 & $T$ & $C$ & $C$ & $C$ & $C$ & $C$ & $C$ & $T$ & $T$ & $C$ & $C$ \\
\hline 532 & C & C & C & C & $T$ & C & C & C & C & C & C \\
\hline 585 & $A$ & A & A & $\mathrm{C}$ & $\mathrm{C}$ & $\mathrm{C}$ & $\mathrm{C}$ & A & A & C & $\mathrm{C}$ \\
\hline 602 & C & $\mathrm{C}$ & C & $\mathrm{C}$ & A & $\mathrm{C}$ & C & C & C & C & $\mathrm{C}$ \\
\hline 694 & (CAA) 18 & (CAA) 8 & (CAA) 7 & (CAA) 15 & (CAA)19 & (CAA) 26 & (CAA)31 & (CAA) 17 & (CAA) 20 & (CAA) 15 & $(\mathrm{CAA}) 16$ \\
\hline 755 & $\mathrm{~T}$ & C & $C$ & $C$ & $C$ & C & C & $\mathrm{T}$ & $\mathrm{T}$ & $C$ & $C$ \\
\hline
\end{tabular}

Figure 5. Differences in nucleotide sequence among 11 haplotypes of the pseudogene GAG56B. Differences with respect to haplotype 1 are marked in grey. Positions are counted from the beginning of the primer employed in the DNA amplification.

Four main observations have been drawn from these results.

Firstly, in most cases, any allele at the Gli-B1 locus (identified through APAGE analysis of the set of gliadin polypeptides) occurring in different cultivars has an identical sequence 
for the $\gamma$-gliadin pseudogene GAG56B. For example, haplotype 2 was registered in two unrelated cultivars from two countries with allele Gli-B1n, haplotype 4 occurred in three cultivars with Gli-B1c, and haplotype 5 in three cultivars from three countries with Gli-B1h (Table 2). Therefore, there was a clear congruity of the polymorphisms in the expressed (Gli-B1-encoded $\gamma$-gliadin) and noncoding ( $\gamma$-gliadin pseudogene) parts of the Gli-B1 locus. The allele Gli-B1c belongs, in this test, to variant IV.

Secondly, 11 haplotypes of the pseudogene GAG56B were divided into seven deeply diverging groups similar to those revealed by other methods in our work: alleles Gli-B1i, $k$, m, o (variant I: haplotype 1); Gli-B1n, q, s (II: 2); Gli-B1b (III: 3); Gli-B1e, g, f, c (IV: 4); Gli-B1h (V:5); Gli-B1d (VI: 6); and Gli-B1a (VII: 7) (Figure 5). The smallest differences were observed between alleles of groups II and III (substitution at position 182 and a minimal difference in the length of the SSR sequence) and of the groups IV and VII (a difference in the length of the SSR sequence). More differences were found between variants I, IV + VII and II + III, while the greatest difference was observed between variants I and V (substitution in 10 positions and in the length of the SSR) (Figure 6).

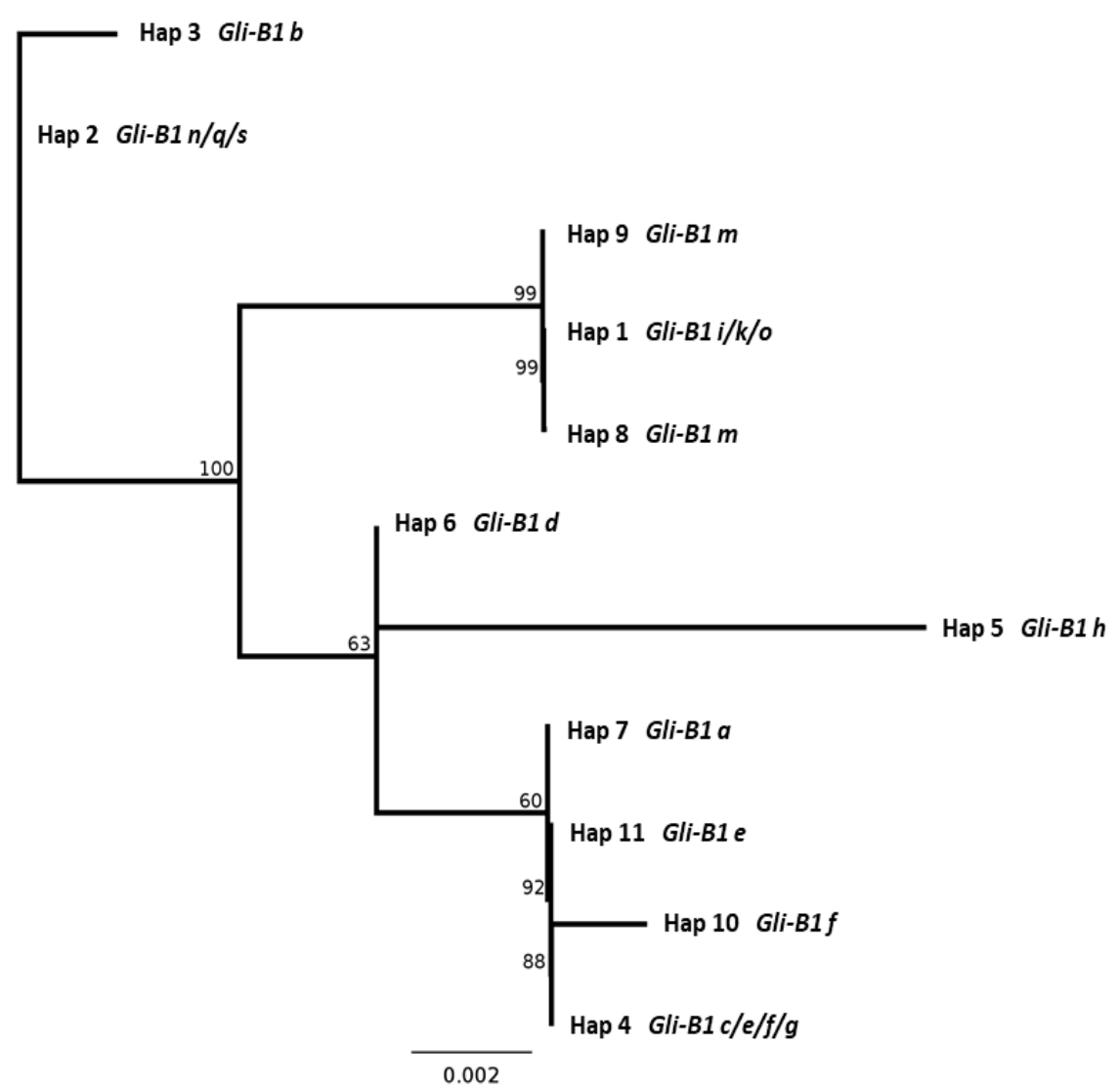

Figure 6. Relationships among allelic variants of the Gli-B1 locus based upon the sequence of the pseudogene GAG56B located within the Gli-B1 locus.

Thirdly, there was one case of a fine difference between alleles belonging to the same group (as has been found using the RFLP approach): the allele Gli-B1m differed slightly from other alleles of variant I by the length of its SSR sequence (Figure 5, Table 2).

Fourthly, there were three alleles (identified by APAGE) for which the GAG56B sequence differed among wheat genotypes: Gli-B1m (haplotypes 1, 8 and 9), Gli-B1e (4 and 11) and Gli-B1f (4 and 10) (Figure 6, Table 2). The difference might be caused by a mutational change in a given allelic variant of the Gli-B1 locus causing the appearance of a new haplotype of the pseudogene studied. For example, an expansion of the CAA repeats present inside the GAG56B pseudogene converts allelic variant Gli-B1e (the cultivar Glenlea, haplotype 4 , usual for alleles of variant IV) into the new variant of the same allele (the 
cultivar Saratovskaya-36, haplotype 11). Three variants of the allele Gli-B1m differed in the number of the CAA repeats $(18,17,20)$, while the only substitution in position 348 distinguished haplotype 4 from 10 (Figure 5, Figure S4). Any allele at Gli-B1 (for example, Gli-B1m), harboring different haplotypes of the GAG56B pseudogene in different cultivars, always produces the same set (a block) of encoded gliadins (data not shown).

Finally, a close similarity was noticed between two different trees of genetic distances, based, firstly, on the RFLP-RsaI data (Figure 3b), and, secondly, on the sequencing of the GAG56B pseudogene (Figure 6).

\section{Discussion}

Differentiation of homologous chromosomes exists among genotypes of self-pollinated species. In Triticum aestivum, differences between homologs in their heterochromatin banding were documented [30]. Intraspecific polymorphism was mostly expressed for chromosomes of the B genome [31]. Due to chromosome-specific variation, the number of chiasmata and pairing of homologous chromosomes in F1 hybrids between cultivars was reduced compared to that of their parental inbred lines [32]. The observed recombination frequency between genetic markers depends upon the level of differences between the chromosomes of the parental cultivars involved in the cross [32,33].

Homologous chromosomes present in different wheat genotypes were called "heterohomologous" to differentiate them from euhomologous (veritably homologous) chromosomes present in a given genotype. The differences among heterohomologues are distributed along the chromosomes involved and are assumed to be due to differences in the non-coding portion of DNA sequences [34,35]. Deletions of small DNA sequences [36], the presence of different sets of transposable elements and variation in the number of their blocks located between genes [14,16,22,37], as well as SNP [38,39], may contribute to the differences between heterohomologous chromosomes.

The existence of several quite different variants of the DNA sequence at the Gli-B1 locus of common wheat has been documented in our work. These variants could be designated, analogously to heterohomologous chromosomes, as "heteroallelic", and alleles belonging to the same variant would be "homoallelic".

RFLP seems to be especially useful for the comparison of allelic versions of a Gli locus, because restriction sites for a given endonuclease may occur at any location along the whole long gliadin locus, including expressed genes and non-coding sequences. Using the RFLP approach permitted several distinct variants of DNA sequences of the Gli-B1 locus to be documented, strongly differing (without intermediate forms) in their restriction site positions. Moreover, some fine differences between alleles belonging to the same variant were revealed.

The length of the PCR products of the $\gamma$-gliadin SNP markers and sequencing the PCR products of the pseudogene GAG56B were used for more detailed analysis of two particular regions of the non-coding DNA inside the Gli-B1 locus. In general, analysis of coding and non-coding parts of 15 allelic variants of the Gli-B1 locus revealed at least seven "heteroallelic" variants of the Gli-B1 locus (I-VII) without intermediate forms between them. Two pairs of allelic variants (II and III; IV and VII) were more closely related than the others. Nevertheless, allele Gli-B1a (variant VII, which was only documented in the genotype of the local variety Chinese-Spring), for example, differed from alleles of variant IV by the EM (APAGE) of the encoded $\gamma$-gliadin (Figure 1, Figure S1), by the RFLP-TaqI test (Figure 3a), by the length of the PCR product (Figure 4 ) and by the sequence of the pseudogene GAG56B (Figures 5 and 6).

The allele Gli-B1c was identical to other alleles of group IV in the RFLP test (endonucleases TaqI and RsaI) and in PLP and GAG56B tests but differed from them in another RFLP test (HaeIII) and in APAGE. Therefore, we assume Gli-B1c is one more variant (VIII) related to group IV.

Earlier, six contrasting variants without intermediate forms were described for DNA sequences of the Glu-B1 locus (B genome) among 58 cultivars of tetraploid and hexaploid 
wheat. It was suggested that these variants were present in genotypes of the diploid donors of this genome [13].

The pathways of origin of hexaploid wheat through successive crosses between diploid donors of the $\mathrm{A}$ and $\mathrm{B}$ genomes, and later, between $\mathrm{AB}$ and the $\mathrm{D}$ genome, are known in detail [40]. Naturally, heteroallelic variants of the Gli-B1 locus might originate from different genotypes of the donor(s) of the B genome in hexaploid wheat, as suggested by [41], and inherit particularities of the Gli-B1 locus of these donors. It is suggested that genotypes of the diploid donors of genomes $\mathrm{A}, \mathrm{B}$ and $\mathrm{D}$ were already highly polymorphic before the origin of allopolyploids [42] and that crosses between wild tetraploids and young forms of hexaploid wheat [43] might also have contributed to the currently observed polymorphism of common wheat. A recent study showed great variation in common wheat germplasm (extensive structural rearrangements of DNA sequences and gene content) resulting from the history of wheat breeding aimed at improving different wheat characteristics, such as grain yield and quality, resistance to stresses and diseases, and adaptation to conditions of growth [44].

Analysis of the gliadin genotypes in about 1000 common wheat worldwide cultivars of the 20th century (Table S1 in [11]) showed that five main versions of heteroalleles (I, III, IV+VIII, V, VI) at the Gli-B1 locus not only dominate in the germplasm studied but are also spatially structured around the world and probably adapted to regional eco-climatic environments [45]. We suggest that genetic diversity at the Gli-B1 locus of common wheat germplasm studied is based mainly on the differences between variants of genotypes inherited by hexaploid wheat from its diploid donor(s) of the B genome. The donor(s) supplied common wheat with its own genetic variation of the distal part of chromosome $1 \mathrm{~B}$, which is now observed as heteroallelic variants at the Gli-B1 locus. A considerable downturn in the level of genetic diversity of common wheat for this chromosome region would be caused only by the disappearance (impossible) of one of these variants.

If the level of genetic diversity of wheat germplasm of the 20th century calculated for the Gli-B1 locus depended decisively upon several heteroallelic variants, it would not be as great as that calculated using all (more than 20 [11]) known individual alleles present in registered wheat cultivars. Indeed, several allelic members of one variant might have a mutational origin (for example, alleles of variant I) and not differ among them in any test applied in this work. Although the loss of rare alleles over time may be considered a display of genetic erosion [46], the disappearance of a rare allele (a member of one of the principal variants) would have only a minor influence on the level of genetic diversity.

\section{Materials and Methods}

\subsection{Plant Materials}

The majority of grain samples of the common wheat (Triticum aestivum L.) cultivars used in this work were obtained from genetic and/or breeding laboratories in their countries of origin and studied earlier (Table S1 in [11]). In total, 916 registered cultivars from 18 countries were considered, in which alleles at the Gli-B1 locus were identified [11].

For this work, some grain samples not studied earlier were taken from local collections in Italy, Spain and Ukraine. Also included in the study were grain samples not studied earlier of several registered cultivars and important genotypes (for example, Chinese Spring), plus several Spanish landraces. The widest possible, first, allelic variation at the Gli-B1 locus and, second, origin of cultivars were thereby covered.

Names of cultivars, country of origin, year of registration and spring/winter habit were taken from the CIMMYT GRES database [47].

\subsection{Molecular Analysis}

In the current work, some grain samples from local collections were analyzed with the aim of confirming their gliadin genotypes. To do this, an acid polyacrylamide gel electrophoresis (APAGE) routine procedure [11] was used. Two-dimensional electrophoresis $($ APAGE $\times$ SDS-electrophoresis, TDE) was performed as previously described [28]. 
For RFLP analysis, DNA was extracted from seven-day-old seedlings) using a modified CTAB procedure [48]. DNA digestion, gel electrophoresis, blotting and hybridization were carried out as described by Gebhardt et al. [29,49]. For the identification of the $\gamma$ gliadin DNA sequences, the probe K32 (the cDNA clone) specifically recognizing these sequences was applied [50].

DNA was extracted from dry single seeds using the CTAB method [51]. DNA qualities were evaluated on agarose gels, and DNA concentrations were determined spectrophotometrically using an ND-1000 instrument (Thermo Fisher Scientific, Wilmington, North Carolina, USA). All extractions were diluted to $100 \mathrm{ng} / \mu \mathrm{l}$ and stored at $-20{ }^{\circ} \mathrm{C}$ until being used.

PCR amplification was performed in the thermocycler Analytik Jena (Flex Cycler, Jena, Germany) using GliB1.1 and GliB1.2 primers [25]. Products of amplification for each cultivar (three or more single seeds per cultivar were studied) were fractionated in $7 \%$ polyacrylamide gels $(280 \mathrm{~V})$ for two hours and stained as proposed by the Silver sequence TM DNA Sequencing System Technical Manual (Promega, Madison, WI, USA). The lengths of the amplification products were compared in neighboring lanes of the same slab gel. The approximate length of the product of amplification for each cultivar was calculated using standard markers with fragments of known length.

$\gamma$-Gliadin gene GAG56B was amplified with GAG29 and GAG30 primers [24]. PCRamplified fragments were purified with sepharose columns and sequenced by capillary electrophoresis at Macrogen (Macrogen Europe, Amsterdam, The Netherlands). Sequences were analyzed with Sequencher ${ }^{\circledR}$ version 5.0 sequence analysis software (Gene Codes Corporation, Ann Arbor, MI, USA) and aligned with acn M13712 in order to detect polymorphisms. The information obtained was used to reconstruct GAG56B for each cultivar and to define haplotypes. DNA sequences were aligned using clustalW [52]. Phylogenetic trees from the nucleotide alignment were calculated employing the Neighbor-joining method, with Jukes-Centre distance and 100 bootstrap.

The trees of the relationship between alleles at the Gli-B1 locus based on the RFLP data were also designed by the Neighbor-joining method.

Supplementary Materials: Supplementary materials can be found at https: / www.mdpi.com/14 22-0067/22/4/1832/s1. Figure S1: Schemes of blocks of jointly inherited gliadin bands (APAGE) controlled by alleles at the Gli B1 locus studied, Figure S2: Two dimensional (APAGE $\times$ SDS) gliadin separations of Spanishlandraces, Figure S3: The RFLP patterns (restri ctase Taq I) of some common wheat cultivars, Figure S4: Nucleotide sequences of the $\gamma$ gliadin pseudogene GAG56B in the common wheat cultivars studied, Table S1: Cultivars with different alleles at the Gli B1 locus studied by two dimensional (APAGE $\times$ SDS) electrophoresis.

Author Contributions: E.M. designed the study; E.M., L.P., P.V., V.M., M.R.-Q., Y.P., and S.C. performed experimental work and analyzed the results. E.M. and W.J.R. valorized the results and wrote the manuscript. All authors have read and agreed to the published version of the manuscript.

Funding: This research was funded by Spanish Ministerio de Ciencia e Inovacion, grant number PID2019-109089RB-C32.

Institutional Review Board Statement: Not applicable.

Informed Consent Statement: Not applicable.

Data Availability Statement: Not applicable.

Conflicts of Interest: The authors declare no conflict of interest.

\section{References}

1. FAOSTAT (Food and Agriculture Organization of the United Nations). Available online: http://www.fao.org/faostat/es/\#data/ QC (accessed on 25 January 2021).

2. Marcussen, T.; Sandve, S.R.; Heier, L.; Spannagl, M.; Pfeifer, M.; Jakobsen, K.S.; Wulff, B.B.; Steuernagel, B.; Mayer, K.F.; Olsen, O.A.; et al. Ancient hybridizations among the ancestral genomes of bread wheat. Science 2014, 345, 1250092. [CrossRef] 
3. Redaelli, R.; Metakovsky, E.; Davydov, S.D.; Pogna, N.E. Two-dimensional mapping of gliadins using biotypes and null mutants of common wheat cultivar Saratovskaya 29. Hereditas 1994, 121, 131-137. [CrossRef]

4. Gobaa, S.; Bancel, E.; Branlard, G.; Kleijer, G.; Stamp, P. Proteomic analysis of wheat recombinant inbred lines: Variations in prolamin and dough rheology. J. Cereal Sci. 2008, 47, 610-619. [CrossRef]

5. Barak, S.; Mudgil, D.; Khatkar, B.S. Biochemical and functional properties of wheat gliadins: A review. Crit. Rev. Food Sci. Nutr. 2015, 55, 357-368. [CrossRef]

6. Qi, P.F.; Wei, Y.M.; Ouellet, T.; Chen, Q.; Tan, X.; Zheng, Y.L. The $\gamma$-gliadin multigene family in common wheat (Triticum aestivum) and its closely related species. BMC Genom. 2009, 10, 168-181. [CrossRef] [PubMed]

7. Anderson, O.D.; Huo, N.; Gu, J.Q. The gene space in wheat: The complete $\gamma$-gliadin gene family from the wheat cultivar Chinese Spring. Funct. Integr. Genom. 2013, 13, 261-273. [CrossRef]

8. Payne, P.I.; Holt, L.M.; Lawrence, G.J.; Law, C.N. The genetics of gliadin and glutenin, the major storage proteins in the wheat endosperm. Qual. Plant. Plant Foods Hum. Nutr. 1982, 31, 229-241. [CrossRef]

9. Metakovsky, E.; Chernakov, V.M.; Upelniek, V.P.; Redaelli, R.; Dardavet, M.; Branlard, G.; Pogna, N.E. Minor w-gliadin-coding loci on chromosome 1A of common wheat: A revision. J. Genet. Breed. 1996, 50, 277-286.

10. Sozinov, A.A.; Poperelya, F.A. Genetic classification of prolamins and its use for plant breeding. Ann. Technol. Agric. 1980, 29, 229-245.

11. Metakovsky, E.; Melnik, V.A.; Rodriguez-Quijano, M.; Upelniek, V.P.; Carrillo, J.M. A catalog of gliadin alleles: Polymorphism of 20th-century common wheat germplasm. Crop J. 2018, 6, 629-641. [CrossRef]

12. Shewry, P.R.; Halford, N.G. Cereal seed storage proteins: Structures, properties and role in grain utilization. J. Exp. Bot. 2000, 53, 947-958. [CrossRef] [PubMed]

13. Blatter, R.H.E.; Jacomet, S.; Schlumbaum, A. About the origin of European spelt (Triticum spelta L.): Allelic differentiation of the HMW Glutenin B1-1 and A1-2 subunit genes. Theor. Appl. Genet. 2004, 108, 360-367. [CrossRef]

14. Huang, X.Q.; Cloutier, S. Molecular characterization and genomic organization of low molecular weight glutenin subunit genes at the Glu-3 loci in hexaploid wheat (Triticum aestivum L.). Theor. Appl. Genet. 2008, 116, 953-966. [CrossRef] [PubMed]

15. Gill, K.S.; Gill, B.S.; Endo, T.R.; Taylor, T. Identification and high-density mapping of gene-rich regions in chromosome group 1 of wheat. Genetics 1996, 144, 1883-1891. [CrossRef] [PubMed]

16. Gao, S.; Gu, Y.Q.; Wu, J.; Coleman-Derr, D.; Huo, N.; Crossman, C.; Jia, J.; Zuo, Q.; Ren, Z.; Anderson, O.D.; et al. Rapid evolution and complex structural organization in genomic regions harboring multiple prolamin genes in the polyploid wheat genome. Plant. Molec. Biol. 2007, 65, 189-203. [CrossRef]

17. Anderson, O.D.; Litts, J.C.; Greene, F.C. The $\alpha$-gliadin gene family. 1. Character ization of ten new wheat $\alpha$-gliadin genomic clones, evidence for limited sequence conservation of flanking DNA, and Southern analysis of the gene family. Theor. Appl. Genet. 1997, 95, 50-58. [CrossRef]

18. Li, W.; Zhang, P.; Fellers, J.P.; Friebe, B.; Gill, B.S. Sequence composition, organization, and evolution of the core Triticeae genome. Plant J. 2004, 40, 500-511. [CrossRef]

19. Charles, M.; Belcram, H.; Just, J.; Huneau, C.; Violett, A.; Couloux, A.; Segurens, B.; Carter, M.; Huteau, V.; Coriton, O.; et al. Dynamics and differential proliferation of transposable elements during the evolution of the B and A genomes of wheat. Genetics 2006, 180, 1071-1086. [CrossRef]

20. van Herpen, T.W.J.M.; Goryunova, S.V.; van der Schoot, J.; Mitreva, M.; Salentijn, E.; Vorst, O.; Schenk, M.F.; van Veelen, P.A.; Koning, F.; van Soest, L.J.M.; et al. Alpha-gliadin genes from the A, B, and D genomes of wheat contain different sets of celiac disease epitopes. BMC Genom. 2006, 7, 1-12. [CrossRef]

21. Harberd, N.P.; Bartles, D.; Thompson, R.D. Analysis of the gliadin multigene loci in bread wheat using nullisomic-tetrasomic lines. Molec. Gen. Genet. 1985, 198, 234-242. [CrossRef]

22. Gu, Y.Q.; Crossman, C.; Kong, X.; Luo, M.; You, F.M.; Coleman-Derr, D.; Dubcovsky, J.; Anderson, O.D. Genomic organization of the complex $\alpha$-gliadin gene loci in wheat. Theor. Appl. Genet. 2004, 109, 648-657. [CrossRef] [PubMed]

23. Anderson, O.D.; Dong, L.; Huo, N.; Gu, Y.Q. A new class of wheat gliadin genes and proteins. PLoS ONE 2012, 7, e52139. [CrossRef] [PubMed]

24. Von Büren, M.; Lüthy, J.; Hübner, P. A spelt-specific $\gamma$-gliadin gene: Discovery and detection. Theor. Appl. Genet. 2000, 100, 271-279. [CrossRef]

25. Zhang, W.; Gianibelli, M.C.; Ma, W.; Rampling, L.R.; Gale, K.R. Identification of SNPs and development of allele-specific PCR markers for gamma-gliadin alleles in Triticum aestivum. Theor. Appl. Genet. 2003, 107, 130-138. [CrossRef] [PubMed]

26. Pogna, N.E.; Metakovsky, E.; Redaelli, R.; Raineri, F.; Dachkevitch, T. Recombination mapping of Gli-5, a new gliadin-coding locus on chromosome 1A and 1B in common wheat. Theor. Appl. Genet. 1993, 87, 113-121. [CrossRef] [PubMed]

27. Pogna, N.E.; Lafiandra, D.; Peillet, P.; Autran, J.C. Evidence for a direct causal effect of low molecular weight subunits of glutenins on gluten viscoelasticity in durum wheats. J. Cereal. Sci. 1988, 7, 211-214. [CrossRef]

28. Metakovsky, E.; Melnik, V.A.; Vaccino, P.; Rodriguez-Quijano, M. Comparison of alleles at the Gli-1 loci of common wheat by means of two-dimensional electrophoresis of gliadin and RFLP analysis. Cytol. Genet. Kiev 2018, 52, 11-20. [CrossRef]

29. Vaccino, P.; Metakovsky, E. Gliadin alleles in DNA RFLP patterns of common wheat: Implication for analysis of organization and evolution of complex loci. Theor. Appl. Genet. 1995, 90, 173-181. [CrossRef] 
30. Endo, T.R.; Gill, B.S. Somatic karyotype, heterochromatin distribution, and nature of chromosome differentiation in common wheat, Triticum aestivum L. em Thell. Chromosome 1984, 89, 361-369. [CrossRef]

31. Friebe, B.; Gill, B.S. C-band polymorphism and structural rearrangements detected in common wheat (Triticum aestivum). Euphytica 1994, 78, 1-5.

32. Dvorak, J.; Chen, K.C. Distribution of nonstructural variation between wheat cultivars along chromosome arm 6Bp: Evidence from the linkage map and physical map of the arm. Genetics 1984, 106, 325-333. [CrossRef] [PubMed]

33. Dvorak, J.; Appels, R. Investigation of homologous crossing over and sister chromatid exchange in the wheat Nor-B2 locus coding for rRNA and Gli-B2 locus coding for gliadins. Genetics 1986, 113, 1037-1056. [CrossRef] [PubMed]

34. Dvorak, J.; McGuire, P.E. Nonstructural chromosome differentiation among wheat cultivars, with special reference to differentiation of chromosomes in related species. Genetics 1981, 97, 391-414.

35. Crossway, A.; Dvorak, J. Distribution of nonstructural variation along three chromosome arms between wheat cultivars Chinese Spring and Cheyenne. Genetics 1984, 106, 309-324. [CrossRef] [PubMed]

36. Dvorak, J.; Yang, Z.L.; You, F.M.; Luo, M.C. Deletion polymorphism in wheat chromosome regions with contrasting recombination rates. Genetics 2004, 168, 1665-1675. [CrossRef]

37. Wicker, T.; Yahiaoui, N.; Guyot, R.; Schlagenhauf, E.; Liu, Z.D.; Dubcovsky, J.; Keller, B. Rapid genome divergence at orthologous low molecular weight glutenin loci of the A and A(m) genomes of wheat. Plant Cell 2003, 15, 1186-1197. [CrossRef]

38. Ravel, C.; Praud, S.; Murigneux, A.; Canaguier, A.; Sapet, F.; Samson, D.; Balfourier, F.; Dufour, P.; Chalhoub, B.; Brunel, D.; et al. Single-nucleotide polymorphism frequency in a set of selected lines of bread wheat (Triticum aestivum L.). Genome 2006, 49, 1131-1139. [CrossRef] [PubMed]

39. Ram, S.; Sharma, S.; Verma, A.; Tyagi, B.S.; Peña, R.J. Comparative analyses of LMW glutenin alleles in bread wheat using allele-specific PCR and SDS-PAGE. J. Cereal Sci. 2011, 54, 488-493. [CrossRef]

40. Matsuoka, Y. Evolution of polyploid Triticum wheats under cultivation: The role of domestication, natural hybridization and allopolyploid speciation in their diversification. Plant Cell Physiol. 2011, 52, 750-764. [CrossRef] [PubMed]

41. Metakovsky, E.; Kudryavtsev, A.M.; Iakobashvili, Z.A.; Novoselskaya, A.Y. Analysis of phylogenetic relations of durum, carthlicum and common wheats by means of comparison of alleles of gliadin loci. Theor. Appl. Genet. 1989, 77, 881-887. [CrossRef] [PubMed]

42. Dvorak, J.; Luo, M.C.; Akhunov, E.D.N.I. Vavilov theory of centres of diversity in the light of current understanding of wheat diversity, domestication and evolution. Czech J. Genet. Plant. Breed. 2011, 47, S20-S27. [CrossRef]

43. Dvorak, J.; Akhunov, E.D.; Akhunova, A.R.; Deal, K.; Luo, N.C. Molecular characterization of a diagnostic DNA marker for domesticated tetraploid wheat provides evidence for gene flow from wild tetraploid wheat to hexaploid wheat. Molec. Biol. Evol. 2006, 23, 1386-1396. [CrossRef]

44. Walkowiak, S.; Gao, L.; Monat, C.; Haberer, G.; Kassa, M.T.; Brinton, J.; Ramirez-Gonzalez, R.H.; Kolodziej, M.C.; Delorean, E.; Thambugala, D.; et al. Multiple wheat genomes reveal global variation in modern breeding. Nature 2020. [CrossRef] [PubMed]

45. Metakovsky, E.; Melnik, V.A.; Pascual, L.; Wrigley, C.W. Gliadin genotypes worldwide for spring wheats (Triticum aestivum L.). 2. Strong differentiation of polymorphism between countries and regions of origin. J. Cereal. Sci. 2019, 87, 311-317. [CrossRef]

46. Fu, Y.B.; Peterson, G.W.; Yu, J.K.; Gao, L.; Jia, J.; Richards, K.W. Impact of plant breeding on genetic diversity of the Canadian hard red spring wheat germplasm as revealed by EST-derived SSR markers. Theor. Appl. Genet. 2006, 112, $1239-1247$. [CrossRef] [PubMed]

47. GRIS Database (CIMMYT International Maize and Wheat Improvement Center). Available online: http:/ / wheatpedigree.net/ (accessed on 11 February 2021).

48. Murray, M.; Thompson, W.F. Rapid isolation of high-molecular-weight plant DNA. Nucleic Acid Res. 1980, 8, 4321-4325. [CrossRef]

49. Gebhardt, C.; Ritter, E.; Debener, T.; Schachtschabel, U.; Walkemeier, B.; Uhrig, H.; Salamini, F. RFLP analysis and linkage mapping in Solanum tuberosum. Theor. Appl. Genet. 1989, 78, 65-75. [CrossRef]

50. Bartels, D.; Altosaar, I.; Harberd, N.P.; Barker, R.F.; Thompson, R.D. Molecular analysis of gamma-gliadin gene families at the complex Gli-1 locus of bread wheat (T. aestivum L.). Theor. Appl. Genet. 1986, 72, 845-853. [CrossRef]

51. Doyle, J.J.; Doyle, J.L. Isolation of plant DNA from fresh tissue. Focus 1990, 12, 13-15.

52. Thompson, J.D.; Higgins, J.G.; Gibson, T.J. Clustal W: Improving the sensitivity of progressive multiple sequence alignment through sequence weighting, position-specific gap penalties and weight matrix choice. Nucl. Acid Res. 1994, 22, 4673-4680. [CrossRef] 